\title{
A CRITICAL ANALYSIS OF QUALITY MANAGMENT IMPLEMENTATION IN A SMALL BRAZILIAN COMPANY
}

\author{
Jonathan Schmitz Rauber \\ University of Vale do Rio dos Sinos, Brazil \\ E-mail: john.rauber@gmail.com \\ Marco Antonio Viana Borges \\ University of Vale do Rio dos Sinos, Brazil \\ E-mail:maborges@unisinos.br \\ Márcio Laênio Manoel Júnior \\ University of Vale do Rio dos Sinos, Brazil \\ E-mail:mmanoel.jr@gmail.com \\ Diego Augusto de Jesus Pacheco \\ Universidade Federal do Rio Grande do Sul, Brazil \\ E-mail: profdajp@gmail.com \\ Submission: $21 / 08 / 2013$ \\ Revision: 05/09/2013 \\ Accept: 08/11/2013
}

\section{ABSTRACT}

This research aimed to identify the impact and organizational changes occurred in a small company in the printing supplies sector as it implemented the ISO 9001:2000 standard. The case study methodology was used through exploratory research to conduct semistructured interviews with six employees in addition to participant observation. The desired outcome of this article is the identification of the benefits and difficulties encountered in the implementation process and a comparison between the new and previous practices. The main results of the research relate to the process of professionalization of management practices of the company and the improved internal processes.

Keywords: ISO 9001; small company; organizational changes. 
INDEPENDENT JOURNAL OF MANAGEMENT \& PRODUCTION (IJM\&P) http://www.ijmp.jor.br

v. 5, n. 2, February - May 2014. ISSN: 2236-269X

DOI: 10.14807/ijmp.v5i2.121

\section{INTRODUCTION}

According to Sartori and Weise (2013), the total quality management seeks constant improvement and a gradual introduction of new processes both existing in order to achieve greater excellence in quality organizations as a whole. The intensity of global competition has required companies to rethink their strategies in order to increase competitiveness, profitability and, at the same time, thrive on the market in which they work. In order to have a management development, it is necessary to supplement with quality tools, and management tools, which help in the overview of the organization and also in the processes and services.

In this sense, according to the International Organization for Standardization (ISO) annual survey, by the end of 2007, over 951 thousand companies in 175 countries had won a certification based on the ISO 9001:2000 quality management system. This number represents an increase of approximately $6 \%$ over the previous year. Compared to previous increases, $15 \%$ in 2006 and 17\% in 2005, this number may be considered low. However, in Brazil, by the end of the same period, the total number of ISO 9001:2000 certified companies had reached 15.384, representing an increase of more than $70 \%$ compared to 2006 (ISO, 2007). According to a survey carried out by the Brazilian Quality Committee (ABNT/CB-25) in 2005, more than half the companies seeking the certification in Brazil are small B2B companies facing a decrease in market share since many of their possible customers demand a quality certification from their suppliers, in most cases, the ISO 9001:2000.

Although ISO 9001:2000 has been present in Brazil and in the international scenario for a number of years now bringing many benefits to the companies and their customers, Szyszka (2001) states that many companies ignore it believing that the certification is only for large and multinational companies due to its cost. This way of thinking is erroneous, though, since, as aforementioned, the survey sponsored by the Brazilian Quality Committee showed that more than half the companies certified in 2007 were small companies.

In view of that, this article aims to identify and critically analyze the effects of the ISO 9001:2000 implementation process in a small Brazilian company in the printer supplies business. The purpose of this article is to answer the following research question: What were the main effects and changes occurred as the ISO 
DOI: 10.14807/ijmp.v5i2.121

9001:2000 standard was implemented in a small company dealing in printer supplies? To conduct this investigation, this article was organized as follows: section 2 presents a brief theoretical and analytical framework on quality and the ISO standard, which sets the basis for the investigation; in section 3, the research outline is characterized and justified; section 4 presents the development steps of the case study in the company; section 5 shows an analysis and a discussion of the perceptions derived from the development; and, lastly, section 6 covers the conclusions and the limitations that were identified and suggestions for future research work.

\section{QUALITY MANAGEMENT}

Deming (1990) states that the quality of a product or service can only be defined by the customer. The author also stresses the point that quality is a relative term that changes its meaning as the customer requirements evolve. To live up to, or exceed, customer expectations, managers must realize the importance of customer surveys. Likewise, Juran (1995) defines quality as the level of satisfaction achieved by a certain product as it meets the user's objectives during its use, which is called "fitness for intended use".

According to Garvin (2002), quality can be defined through the following five approaches: i) Transcendent quality: synonymous of "innate excellence", i.e., learning to recognize by experience. The transcendent approach equals quality to fine handcraft and a rejection of mass production, i.e., it values effort and seriousness. It is a subjective approach, with no pre-defined standards and concepts to measure and affirm whether or not a product has quality; ii) Product-based quality: considered as a precise and measurable variable. The quality differences reflect differences in the quantity of some ingredient or attribute of a certain product; iii) User-based quality: based on the premise that quality is in the eye of the beholder; iv) Production-based quality: identifies quality based on the production such as conformity to specifications; v) Value-based quality: considers that a quality product offers a performance or conformity at an acceptable price or cost, i.e., the excellence we can buy.

According to Santos and Martins (2010), quality management has become increasingly important in terms of measuring, quantitative methods, specialised 
teams and clearly defined performance goals. These ideas seem demonstrate that the search for quality is fundamental to any company, especially in markets where products are homogeneous, as is the case of printer supplies since it is a way to get a competitive edge and a strategic differential. Companies that do not invest in quality are losing share of market to companies that do and reap results through customer loyalty and high profitability from the satisfied customer, achieving this by reducing production wastes, streamlining operations and making them more efficient.

\subsection{ISO 9000}

According to Arnold (1994), the ISO 9000 series, currently ISO 9001:2000, is a set of guidelines for the design, manufacture, sales and support for a product or service. Its successful implementation requires that the implementation team consider the standard as a complete "clause" for the design, manufacture, sales and support. The system to be developed should be based on firmness of purposes and has as its goal the requirements of business practice. In other words, the ISO 9000 series consists of guidelines for conducting business globally.

Delazaro Filho et al. (1996) state that the certification of a company demonstrates that it possesses a well-organized work force and that its products are reliable. Therefore, it can affirm to its customers that it is a world class manufacturer. To Cerqueira (1999), the ISO 9000 series signals the need to take into consideration the expectations of internal and external customers as well as all of the organization's stakeholders.

According to the International Organization for Standardization (2009), the NBR ISO 9001:2000 standard is based on 8 quality management principles:

- Customer focus - organizations depend on their customers, therefore they ought to understand their customers' current and future requirements, meet those requirements and seek to exceed their expectations;

- Leadership - the leaders are responsible for establishing the purposes and giving direction to the organizations, in addition to creating and maintaining an internal environment where people are fully engaged in the achievement of the organization's objectives; 
DOI: 10.14807/ijmp.v5i2.121

- Involvement of people - people are the essence of an organization (independently of their levels) and it is their involvement that drives them to use their abilities to the company's benefit;

- Process approach - the desired result is achieved more efficiently when the activities and their associated resources are managed as a process;

- System approach to management - identifying, understanding and managing interrelated processes since a system contributes to the efficacy and efficiency of the organization as it moves toward its objectives;

- Continuous improvement - the continuous improvement of the organization's overall performance should be its ongoing objective;

- Factual approach to decision making - efficacious decision making is based on an analysis of data and information;

- Mutually beneficial relationships with suppliers - an organization and its suppliers are independent and a mutually beneficial relationship increases their ability of adding value.

Moura e Carillo Jr. (1994) believes that the standards of the ISO 9000 series were created to be used in three situations:

- Contractually, between customer and supplier: when the customer is interested in elements of the supplier's system of quality that have a bearing on the customer's production process of goods or services. In other words, the customer opts for a certain quality assurance model and requires by means of a contract that the elements comprising the chosen standard be an integral part of the supplier's quality system;

- Customer's approval or registration of the supplier's quality system: the customer is interested in evaluating the supplier's quality system to verify that it is compatible with its chosen standard of quality. The customer uses the standard as a benchmark for the evaluation and may issue a formal recognition that the system is compliant with the standard. It is normally used for the purpose of indicating approval and registration of the supplier in the customer files; 
DOI: 10.14807/ijmp.v5i2.121

- Certification or registration of the supplier's quality system by a certifying agency or to provide guidance for the quality management system: the supplier is appraised by a certifying agency and commits itself to maintain the quality system for all the customers, except when otherwise specified. The certifying agency issues a formal recognition that the quality system is compliant with the standard for a given period of time. This type of certification and registration of the quality system reduces the number of audits to be performed.

\subsection{Criticism and Benefits of ISO 9000}

One of the strongest criticisms to the ISO 9000 series is that it limits the company's flexibility. Some authors make this point arguing that if everything a company produces must be previously described, the company will end up as a hostage of its own standards. In other words, there would be no room for flexibility. In addition to that, there is also some criticism about what refers to the people who work for the company. According to Litmanowicz (1995), ISO 9000 covers only a part of the organization, leaving out of its scope the entire human behavior. According to the author, the company should undergo a cultural change as it would do no good to implement the standard if the organization did not absorb the change into its culture. To him, the certification should be a consequence of the cultural change within the company. Like Limanowicz (1995), Moura e Carillo Jr. (1994) also believes that a gap of the standard underlies the distortions that happen with regard to its true purposes and the little knowledge that people have about the culture of total quality.

Likewise, Roesch (2009) states that many companies take the ISO 9000 standard as if it were a model of total quality. This is not 100 percent true since it is possible to say that the standard is only a system to assure compliance with specifications. The standard does not question whether the levels of specification and their controls are suitable or not. It is up to the company to identify the best practices and processes to be standardized. Crosby (1997) says that the ISO system does not lead companies to doing the right things. As the system is passive, not an operating philosophy, the company should always be looking to improve its processes since the system itself will not. 
In 2005, two research projects were conducted by the Brazilian Quality Committee (ABNT/CB-25) in partnership with INMETRO. The first one, ISO 9000 Certification Credibility Research, presented the main reasons why companies seek the quality certification: customer demand (32\%;); quality improvement $(20 \%)$; better process control (15\%); increased internal standardization (12\%); improved competitiveness (11\%); and better internal organization (10\%). In addition to that, the same research identified the main advantages acquired during the implementation process: improved internal organization (22\%); improved competitiveness $(12 \%)$; improved process control (11\%); increased customer confidence $(11 \%)$; cost reduction (9\%); increased internal standardization (9\%); employee skills development $(9 \%)$; and others (18\%). According to the second research project that the Brazilian Quality Committee (ABNT/CB-25) asked INMETRO to conduct, ISO 9000 Certification - Results Research, the main reasons why the researched companies wanted the certification were: market demand (36\%); company policy $(24 \%)$; winning new markets (23\%); increased productivity $(10 \%)$; and marketing $(7 \%)$.

\section{RESEARCH METHODOLOGY}

As the purpose of this article is to study the ISO 9001:2000 implementation process in a small company to identify the mains effects of implementation. The method of research used was the case study with a qualitative approach. This method is considered the most suitable because it permits a more thorough study and a better qualification of the data collected and analyzed. The case study was conducted in a small company dealing in printer supplies, located in the city of Novo Hamburgo, Rio Grande do Sul. For the sake of confidentiality, the name of the company will not be disclosed; it will be referred to simply as the company studied. The company was chosen because it was in the processes of implementing the ISO 9001:2000 standard when the research was conducted in conjunction with Sebrae, starting in early August 2008.

According to Yin (2005), the data for the case study can come from three different sources of evidences, which can be: documentation; filed registers; interviews; direct observation; participant observation; physical artifacts. For this work, the data was collected by means of semi-structured interviews and participant observation made during company visits. The interviews were performed after the 
DOI: 10.14807/ijmp.v5i2.121

complete implementation of ISO. The in-depth interviews relied on semi-structured questions for the two groups: the first one composed of the company top management and the second group composed of department heads. Altogether, the following six people were interviewed: the Office Supervisor, Tape Supervisor, Inkjet Supervisor, Toner Supervisor, Quality Supervisor and one of the Managing Directors of the company. The six employees interviewed represent all the company departments and roughly 30 percent of the company direct headcount.

The interview questions were framed around the theoretical framework. Two sets of questions were used, one for the Director and one for the department heads (Supervisors) due to their different positions and participation in the process. Frequent visits to the company and talks with the employees and the managers provided the participant observation data input, presented in the following sections. The following data analysis was conducted by means of the content analysis technique of Bardin (2002) and the interpretation of the data collected in relation to ISO theoretical fundamentals. The data collected from the interviews is presented according to the subjects that were discussed, and specific information is referenced to the position of the respective interviewee.

\section{RESEARCH DEVELOPMENT}

The case study company has been in the printer supplies business for over twenty years with 20 direct employees, representatives and outside personnel. Next, we present the development steps of the ISO implementation, in the light of the theoretical framework of ISO principles.

Corroborating the theoretical framework, the interviewees pointed out the following reasons why the company opted for the ISO 9001:2000 standard: customer demand of a certification, market-share increase, marketing gains and the quality assurance as determining factors. According to the Toner Supervisor,

\footnotetext{
"the main reason why we chose ISO is that companies use this standard as a means to select their suppliers. More often than not, they are big companies who demand large amounts. [...] Furthermore, I believe that ISO will be a marketing tool for us to publicize the quality we already have since no other company (competitor) in the southern part of the country has this certification."
}

Besides, the Tape and Office Supervisors cited other factors, such as gains that will come from better company organization, all the way from the organization of 
DOI: 10.14807/ijmp.v5i2.121

materials in the departments to the overall company organization, both with regard to the materials and communication and processes. According to the Tape Supervisor, one of the main reasons why the company opted for ISO was the organization of the company as a whole. In addition to that, he believes that the certification can further assure the quality of its products, which has always been the focus of the company.

\subsection{Customer Focus}

With regard to customers, the first principle among the eight principles established by the International Organization for Standardization, all the interviewees, except for the Quality Coordinator (a new hire), stated that the company has always listened to their customers. In the words of the Office Supervisor, "the company has always worked hard to meet the customers' requirements through customer feedback from informal talks when the orders are taken". However, he remarks that "due to the crisis, in recent years the company began to have more customers in the home market than in the industrial market, which was not the company focus". This fact brought down the number of customer feedback. The increase in the home market represents a longer period between the orders because customers in the home market usually buy products for home use.

The Inkjet Supervisor also pointed out that this change in the customer profile brought about a change in the production area as well. The percentage of refills when the customer brings in his own empty cartridge (toner, inkjet or tape) to be refilled - in the home market is a lot larger. As a result, the number of services rendered by the company increases and the product process gets slower since the cartridge lots per model are smaller. However, ever since the implementation process started out, there have been changes in this service in order to optimize and control it more effectively.

\subsection{Leadership}

It can be observed that, since the implementation process initiated, there have been changes in the jobs of some employees. According to ISO, the leadership plays a vital role in the organization. Hence, some changes have occurred in the way some 
of the Supervisors (leaders) behave. Currently, production supervisors (toner, inkjet and tape) believe that, in addition to running their department, they should also look for a greater employee and departmental involvement with the achievement of the company goals. Says the Tape Supervisor:

"I feel I have a lot more responsibility than I used to have. [...] When the implementation of the standard initiated, supervisors started to play a different role - they became leaders of their departments. [...] I have now a lot more autonomy in my department. I discuss ideas with the people and I try to get them to speak up."

Similarly, the Supervisor of Inkjet believes that with his increased responsibilities and duties, the other employees will have to cooperate more if the performance desired is to be met. Therefore, the supervisors have to incentivize and encourage employees to achieve stretch goals. The Toner Supervisor added that the leadership should not be provided by the company Directors alone. The leadership should be disseminated across the entire organization (Directors, Supervisors and employees alike).

\subsection{Involvement of People}

This change in the way supervisors act has brought about a greater degree of employee involvement, and they are the essence of the organization - generating a better utilization of their abilities. According to the Tape Supervisor, employees feel that they are more recognized than they used to be before the ISO implementation process started since their opinions are listened to. The Toner Supervisor described the employee involvement in his department with the following sentence: "People were so enthusiastic that when we were implementing 5S, they asked if they could come in on Saturday afternoon to tidy up the department, since they didn't have enough time during the workweek."

When the interviews were conducted, it was observed that, although most people are aware of how important this process is for the company, some employees hope to gain something at the end of the process (certification), receive some kind of reward, not necessarily money, but they do hope to get something in exchange. This fact indicates a communication problem because the supervisors never mentioned, at any one time, that the employees would get something in return for their contribution to the certification. 


\subsection{System Approach to Management}

According to the Toner Supervisor, the greater employee involvement has contributed not only to the department where they work, but to the entire production system. He believes that the creation of the internal customer-supplier chain at the inception of the implementation process was vital so that every employee could see their dependence from other internal suppliers and, mainly, their importance to the external customers. The Office Supervisor added: "Now, the departments are a lot more aware of their interdependence. [...] everybody knows their needs and duties in the internal customer-supplier chain."

The Tape Supervisor says that this greater interaction between the departments took place principally as a result of the improved internal communication. Had the internal communication not improved, all the work done by the company, mainly those jobs involving two or more departments, could hardly hope to reap the desired results. It seems to be unanimous the fact that the improved internal communication between the departments, and particularly between the office and the toner section, was responsible for the increased cooperation.

\footnotetext{
"There used to be many problems between the office and the toner section. Today, after a number of talks and discussions, the problem has been fixed. Of course, there's always something to be improved, but there's no comparison to what it used to be. ["...] Both departments now understand that they have to cooperate with each other." (Toner Supervisor).
}

The Managing Director mentioned that the company had been trying to improve the internal communication for a long time. As we have mentioned before, the major problems were in the communication between the office, the inkjet department and the toner department, mainly regarding the office-toner relationship. Several meetings had been held with the supervisors of each department and their employees in order to resolve the issue. However, as the Director put it, the people involved were lacking in commitment and they did not really want to change. As the standard was being implemented, however, the lack of goodwill began to wear off and employee commitment surfaced. He believes that the initial training and the motivational talks given by the consultant, emphasizing the need to collaborate and cooperate with the activities of the company, account for the change of attitude.

\subsection{Process Approach}


DOI: 10.14807/ijmp.v5i2.121

As far as the processes are concerned, few changes were reported. Most processes were standardized with no changes. According to the Quality Supervisor, approximately $90 \%$ of processes continue unaltered and 10\% underwent minor changes. The most discussed change by the interviewees was the change in the refill control, which limited the number of refills per day and formally established a maximum delivery time per customer's requirement and a minimum delivery time according to the production capabilities. With this change in the process, the communication problem between these two departments practically ceased. Before the ISO standard was implemented, the departments did not understand the need for departmental cooperation, they were just focusing the local results: for sales department, to sell more, and for production department, to produce more.

"In the production process, no change occurred, only the standardization. [...] The only change was the implementation of a timetable (office) for the refill control, since we were having some delivery issues." (Toner Supervisor).

"The only change in the process was the refill control for toner and inkjets because the production people were experiencing overload issues and late deliveries. [...] the implementation of the refill control timetable fixed the problem." (Office Supervisor).

\subsection{Continuous Improvement}

According to the ISO standard, the continuous improvement of the overall company performance should be an ongoing objective. The implementation of the ISO standard itself can be deemed a search for improved overall performance as it sets the basis for improvement actions. Generally speaking, the company still has a lot of work to do in terms of continuous improvement. The department heads state that they are all open to new ideas, willing to listen to them and are committed to try them for feasibility.

\footnotetext{
"Although participation is still low, employees feel more at home to speak up and voice their improvement ideas. However, there is still a lot to do in this question." (Tape Supervisor).

"We have been working the hardest of all the departments because we are always looking for new ways to improve. We collect ideas from employees; we research the Web and trade publications. [...] keeping up to date is critical for this process." (Toner Supervisor).
}

In spite of the improved work environment, increased employee involvement and an open book attitude from the supervisors, barriers still remain that hamper a more spontaneous contribution from employees. The interviewees mentioned that over $90 \%$ of contributions come from questions they ask employees, i.e., less than 
$10 \%$ are spontaneous contributions. It is believed that it takes time for employees to gain confidence and come up with ideas and suggestions without prompting.

\subsection{Factual Approach to Decision Making}

One of the eight ISO principles is that an efficacious decision-making depends on a careful evaluation of the information. For this reason, the use of indicators is recommended to aid people with their decision making. According to the interviewees, the company has been using indicators for some time. The indicators, however, are few. In the production area, the only indicators in place are daily productivity indicators per sector and type of product. The Tape Supervisor says: "We could add some indicators and reevaluate others. The utilization of only a few indicators may lead to a poor interpretation of the whole [...] you have to confront the data for a better evaluation."

In the administrative and customer service areas, the only indicators in place are the basic financial indicators, such as sales and working capital and the number of customer complaints (defective product). Therefore, the company should implement other indicators in the production and administrative areas to turn the decision making process more efficacious. Says the Office Supervisor: "We need to implement management indicators in the sales and administrative areas. [...] the only indicators we have in place are basic." In this sense, according to the Toner Supervisor, in addition to revising the existing indicators, there are other indicators being created by the quality department in conjunction with the supervisors of every department. The company director stressed the need and the importance of adopting new indicators and using them for a more efficient and efficacious decision making and stated: "The quality department people and the head of every department are working together to create new management indicators and to the revise the existing ones."

\subsection{Mutually Beneficial Relationship with Suppliers}

The last ISO principle, the mutually beneficial relationship with suppliers, is present in the company culture. In the data collection phase, all the interviewees declared that the company-supplier relationship has always been cooperative. According to the Director, "the company has always looked at suppliers as partners, since we need them and they need us [...] we look for a win-win relationship." 


\begin{abstract}
"The company has always maintained partnerships with our customers. For instance, in the office, nearly $100 \%$ of suppliers of materials are company customers. Roughly $50 \%$ of our customers are bookstores, stationery stores, etc. [...] we go out of the way to buy from various customers due to their large number. Of course, we end up buying from the bigger customers, the ones who buy the most from us. [...] it is a win-win relationship between the parties. The company always tries to collaborate with customers. [...] in the production area, the company has a good relationship with suppliers too." (Office Supervisor).

"It is fundamental for the company to maintain a good relationship with suppliers [...] The company maintains a partnership with more than one supplier of raw materials, i.e., there is always a second trusty supplier option." (Toner Supervisor).
\end{abstract}

The dissemination of this good relationship with suppliers became more important in recent months due to the reduction of inventory and the cost that it represents. The strategy of the company is to maintain a low inventory of raw materials, and this calls for a collaboration of everyone in view of the increased control of inventory that is required, in addition to the increased dependence on suppliers. In the case of delivery non-conformances, the company runs the risk of stalling for lack of raw materials.

\title{
5. ANALYSIS AND DISCUSSION OF RESULTS
}

Of all the changes so far, it seems that the one that caused the greatest impact on the employees was the improvement of internal communication between a production section (toner and inkjet) and the office. The employees unanimously stressed the importance of this improvement. In addition to that, the better internal organization, particularly, the reduction of informality and the application of $5 \mathrm{~S}$ procedures, were also highlighted by the Director, the Quality Supervisor and the Tape Supervisor.

Generally speaking, it can be observed that despite the increased responsibility and work, most employees are happy with the ISO 9000 implementation process. The only complaints were the buildup of tasks and the increased paperwork; however, everyone is content with the results so far. According to the Toner Supervisor, "all the changes so far have been positive for the company, but there is still room for improvement." The Tape Supervisor states that "the ISO implementation is very good. It was high time for it. It should have been implemented years ago, but it is better late than never". He also highlighted the gains in organization and communications. 
DOI: 10.14807/ijmp.v5i2.121

From the standpoint of the Quality Supervisor, the main change was that the company as a whole became more professional. The company moved from a familymanaged business to a much more professional profile. We didn't even have an organization chart. Now, the company informality is decreasing and people are beginning to adapt themselves. This change is being accomplished to the management support. Cooperation and support from the top management is fundamental, not just look forward to results.

In his interview, the Director mentioned that the expenditure with the implementation process is minimal if compared to the gains the company had so far. The major expense so far has been the Quality Supervisor, a new hire to run the entire implementation process. Other expenses include the fees of the certifying body, training and consultants fees. However, the major benefit, according to the Director, is the improvement of the organization as a whole, cost reduction, rework reduction, increased productivity, waste reduction, a better communication, among others. Although there are not many indicators, the Director highlights that from the inception of the process, productivity gains and increased sales could be observed. Board 1 shows examples of summary results identified in the interviews. The main answers were classed according to specific objectives.

Table 1: Summary results of interviews 


\begin{tabular}{|c|c|c|c|c|c|c|}
\hline & Office & Tapes & $\begin{array}{l}\text { Supervisor } \\
\text { Inkjet }\end{array}$ & Quality & Toner & Director \\
\hline \multirow[b]{2}{*}{$\begin{array}{l}\text { Motivating } \\
\text { aspects }\end{array}$} & \multicolumn{6}{|c|}{$\begin{array}{l}\text { Customer demands: } \\
\text { Increased market share } \\
\text { Quality assurance }\end{array}$} \\
\hline & $\begin{array}{l}\text { Differential in } \\
\text { MKT } \\
\text { Better internal } \\
\text { organization }\end{array}$ & $\begin{array}{l}\text { Better } \\
\text { housekeeping } \\
\text { Better internal } \\
\text { organization }\end{array}$ & $\begin{array}{l}\text { Better } \\
\text { housekeeping }\end{array}$ & $\begin{array}{l}\text { Customer } \\
\text { service } \\
\text { Productivity }\end{array}$ & $\begin{array}{l}\text { Differential } \\
\text { in MKT }\end{array}$ & $\begin{array}{l}\text { Differential in } \\
\text { MKT } \\
\text { Customer } \\
\text { service } \\
\text { Productivity }\end{array}$ \\
\hline \multirow[t]{2}{*}{ Improvemen } & \multicolumn{6}{|c|}{$\begin{array}{l}\text { Internal communication (particularly between the office and the toner section); } \\
\text { Internal organization }\end{array}$} \\
\hline & $\begin{array}{l}\text { Control of } \\
\text { the processes }\end{array}$ & $\begin{array}{l}\text { Cleanliness } \\
\text { Employees feel } \\
\text { valued }\end{array}$ & Cleanliness & $\begin{array}{l}\text { Less } \\
\text { informality }\end{array}$ & & $\begin{array}{l}\text { Less } \\
\text { informality }\end{array}$ \\
\hline $\begin{array}{l}\text { Difficulties } \\
\text { identified }\end{array}$ & $\begin{array}{l}\text { Lack of } \\
\text { employee } \\
\text { willingness (few) }\end{array}$ & $\begin{array}{l}\text { Buildup } \\
\text { of work }\end{array}$ & $\begin{array}{l}\text { Lack of } \\
\text { employee } \\
\text { willingness - few }\end{array}$ & $\begin{array}{l}\text { Lack of supervisory } \\
\text { leadership } \\
\text { General } \\
\text { informality }\end{array}$ & $\begin{array}{l}\text { Short } \\
\text { time }\end{array}$ & $\begin{array}{l}\text { Break the } \\
\text { paradigm } \\
\text { Comfort zone }\end{array}$ \\
\hline Facilitators & & $\begin{array}{l}\text { Employee } \\
\text { commitment }\end{array}$ & & $\begin{array}{l}\text { Top management } \\
\text { commitment }\end{array}$ & $\begin{array}{l}\text { Employee } \\
\text { commitment }\end{array}$ & $\begin{array}{l}\text { Engagement of } \\
\text { the people in charge } \\
\text { of implementation } \\
\text { Program } \\
\text { "ISO Bound" }\end{array}$ \\
\hline
\end{tabular}

As the board above demonstrates, all the interviewees indicated as the motivating aspects for implementing the ISO 9001:2000 standard the following: customer demand; the company drive to increase the market share; and the quality assurance for the company products and services. Other aspects mentioned include the search for a competitive differential; better internal organization; improved customer service; productivity gains; and better housekeeping. In other words, generally speaking, the entire company presents the same motivating aspects customer demand; search for quality; search for new markets; better internal organization; increased productivity; and marketing - presented by the majority of companies surveyed by the Brazilian Quality Committee.

Just like the main difficulties encountered, the main points identified as process facilitators involve people. However, only those interviewees who did not manifest the difficulties mentioned the commitment of their department employees as a positive factor for the successful implementation. The Quality Supervisor, who had previously manifested the lack of supervisory leadership, praised the top management support to the implementation. The top management, in turn, praised 
DOI: 10.14807/ijmp.v5i2.121

the commitment of the quality section personnel and the Program "ISO Bound" as the main process facilitators.

\section{CONCLUSION}

The purpose of this article was to identify and review the changes occurred during the implementation process of ISO 9001:2000 in a small company in the business of printer supplies, with four specific objectives, which identify the motivating aspects for implementing the ISO 9001:2000 standard, the improvements occurred, the facilitating factors and the difficulties encountered along the way to the present time. The overall objective could be contemplated through an in-depth analysis of these specific objectives.

It can be observed that, in the beginning of the process, one of the most important factors for the good deployment of the process was the involvement and the direct participation of the company top management and the certainty that the ISO implementation would benefit the company. Without the management support and encouragement, the company could have dropped the process, like many other companies did.

Right from the inception of the process until the study was carried out, of all the processes implemented, the one that stood out was the internal communication (particularly between the office and the production section). As the study showed, this was an old problem in the company for which no solution had been found. However, the problem was fixed when a change took place in the process involving the two departments. A timetable was created to control the refill, a simple and efficacious change that practically eradicated the communication problem between the parties. Another change that deserves to be mentioned is the change in the management from informality to professionalism, i.e., the professionalization as a whole.

However, there have been negative points associated with the process. Although there is a great commitment from the company management, the same does not apply to some employees. Most employees are engaged and support the implementation process, but there are a few employees who resist the process, for fear of what will happen or for unwillingness. In addition, some issues have been identified that require attention such as the need of supervisory leadership training. 
DOI: 10.14807/ijmp.v5i2.121

Considering the major limitation of the work is of course the fact of conducting a case study on a single small company for future research to deepen the theme is suggested: i) conduct research of multiple case studies on the impact of the implementation of ISO 9000 in small businesses in the same sector industry in different regions of Brazil, including to identify the influence of contingency factors; ii) empirical research on the critical success factors for implementation of ISO in small businesses; iii) how to integrate other approaches to improve the performance in small business; in this sense, a starting point for future research on these topics can found in the discussion held in Pacheco et al. (2013) and Pacheco (2014).

\section{REFERENCES}

ABNT/CB-25. Pesquisa de credibilidade das certificações ISO 900. Disponível em http://www.abntcb25.com.br/. Acessado em 20 de maio de 2013.

ABNT/CB-25. Pesquisa de resultados - Certificação ISO 9000. Disponível em http://www.abntcb25.com.br/. Acessado em 20 de maio de 2012.

ABNT NBR ISO 9001. (2008) Sistema de gestão da qualidade - Requisitos. Rio de Janeiro. 28 pág. Disponível em http://www.scribd.com/doc/11789290/ABNT-ISO90012008. Acessado em 01 de junho de 2013.

ARNOLD, K. L. (1994) O guia gerencial para a ISO 9000. 1. ed. Rio de Janeiro: Campus, $400 \mathrm{p}$.

CERQUEIRA, J. P. (1999) O sistema ISO 9000 na prática. São Paulo. Ed. Pioneira. CROSBY, P. B. (1997) Controle da Qualidade. São Paulo: Banas.

DELAZARO FILHO, J.; MACHLINE, C.; CARVALHO, A. L.; DELAZARO, W. (1996) Implantação e certificação nas normas ISO 9000. 1. ed. São Paulo: Marcos Cobra, $222 \mathrm{p}$.

DEMING, W. E. (1990) Qualidade: A revolução da administração. 1. ed. Rio de Janeiro: Marques Saraiva, $367 \mathrm{p}$.

GARVIN, D. A. (2002) Gerenciando a qualidade: a visão estratégica e competitiva. Rio de Janeiro. Ed. Qualitymark.

INTERNATIONAL ORGANIZATION FOR STANDARDIZATION (ISO). (2009) Disponível em www.iso.org. Acessado em 05 de abril de 2009.

JURAN, J. M. (1995) Juran na liderança pela qualidade. 3. ed. São Paulo: Pioneira, $386 \mathrm{p}$.

LITMANOWICZ, A. L. A. (1995) Teoria e a Prática da Qualidade - ERA Light. São Paulo, FGV, vol. 2, n. 1.

MOURA, R, A.; CARILLO Jr., E. (1994) Desmistificando a ISO 9000. São Paulo, IMAM. 
PACHECO, D. A. J. et al. (2013) Balanceamento de fluxo ou balanceamento de capacidade: análise e proposições sistêmicas. Ahead to print in Gestão \& Produção.

PACHECO, D. A. J. (2014) Teoria das Restrições, lean manufacturing e seis sigma: limites e possibilidades de integração. Ahead to print in Production.

PRAZERES, P. M. (1996) Dicionário de termos da qualidade. 1. ed. São Paulo: Atlas, $456 \mathrm{p}$.

PROGRAMA GAÚCHO DA QUALIDADE E PRODUTIVIDADE. (2003) Sistema de avaliação - Diagnóstico de gestão: guia de avaliação nível 2. Porto alegre.

ROESCH, S. M. A. (2009) Projetos de estágio e de pesquisa em administração: guia para estágios, trabalhos de conclusão, dissertações e estudos de caso. 3. ed. São Paulo: Atlas, 308 p.

SARTORI, T.; WEISE, A. D. (2013) Models of quality management applied to organizations seeking to innovation management. Independent Journal of Management \& Production, v. 4, n. 1, p. 55-77. January - June.

SANTOS, A. B.; MARTINS, M. F. (2010) Contribuições do Seis Sigma: estudos de caso em multinacionais. Produção, v. 20, n. 1, p. 42-53.

SZYSZKA, Irene. Implantação de sistemas da qualidade ISO 9000 e mudanças organizacionais. Porto Alegre, 2001. 205p.

THE ISSO SURVEY (2007). Disponível em: www.iso.org. Acessado em: 05 de abril de 2009. Disponível em: http://www.iso.org/ - acessado em 28/10/08.

YIN, R. K. (2005) Estudo de Caso. Planejamento e Métodos. 3 ed., Porto Alegre, Bookman. 